\title{
New communication approaches vs. traditional communication
}

\author{
Ioan Constantin Dima ${ }^{1}$, Mirela Teodorescu ${ }^{2, \star}$, Daniela Gîfu ${ }^{3}$ \\ 1University Valahia of Târgovişte, 35 Lt. Stanciu Ion Street, 130105, Târgovişte, Romania \\ ${ }^{2}$ University of Craiova, A. I. Cuza 13, 200585, Craiova, Romania \\ 3“'Alexandru Ioan Cuza” University of Iaşi, Bd. Carol I no. 11, 700506, Romania \\ ^E-mail address: mirteodorescu@yahoo.com
}

\begin{abstract}
The study highlights some communication instances of actual approach of human society evolution in contrast with traditional communication. During the history of communication dates back to prehistory, with significant changes in communication technologies (media and appropriate inscription tools) evolving in tandem with shifts in political and economic systems, and by extension, systems of power (Innis, 1951), communication can range from very subtle processes of exchange, to full conversations and mass communication. Human communication was revolutionized with speech approximately 100,000 years ago, Symbols were developed about 30,000 years ago ( Diringer, 1982) and writing about 5000 years ago, with Aristotle defining first some metrics of communication, remarcable philosophers as Kant, Hegel, Witgestein, Haidegger, Gadamer developing basics of communication, then in XXth century, communication being defined as science, involving all sciences, whole world, because in fact "It is impossible not to communicate" (first axiom of communication). This evolution passed from simple messages, speeches, poems, novels to sophisticated discourses, reducing time response, emphasizing part of messaging, enlarging participation, media involving, persuasion techniques, sound and image in message, all of these convey to viral communication.
\end{abstract}

Keywords: traditional communication; viral communication; neutrosophy; persuasion; conviction

\section{TRADITIONAL COMMUNICATION}

Communication, from Latin commūnicāre, meaning "to share" (Harper, 2013) is the activity of conveying information through the exchange of ideas, feelings, intentions, attitudes, expectations, perceptions or commands, as by speech, gestures, writings, behavior and possibly by other means such as electromagnetic, chemical or physical phenomena. It is the meaningful exchange of information between two or more participants (machines, organisms or their parts) (de Valenzuela, 1992). 
Communicating with others involves three primary steps (Clark, 2013): thought: first, information exists in the mind of the sender, this can be a concept, idea, information, or feeling; encoding: next, a message is sent to a receiver in words or other symbols; decoding: lastly, the receiver translates the words or symbols into a concept or information that a person can understand. Communication requires a sender, a message, a medium and a recipient, although the receiver does not have to be present or aware of the sender's intent to communicate at the time of communication; thus communication can occur across vast distances in time and space. Communication requires that the communicating parties share an area of communicative commonality. The communication process is complete once the receiver understands the sender's message. In Gadamer's opera, hermeneutics is articulated and is defined on the domain of this thesis. As "theory of understanding and mutual understanding", it has the duty to "explain the miracle of understanding" (Gadamer, 2001). The developing of the thesis is performed under "fundamental hermeneutical situation" (Gadamer, 2001) within the main process that takes place is comprehension. To be in the situation, to be in dialogue "means to-be-beyond-the-oneself, to think with the other and return to self as the other" (Gadamer, 2001). Depending on its specific situation can be described: teacher's situation - teaching situation, the converse - an authentic conversation situation (negotiation conversation, medical conversation and confidential conversation) (Borowski, 2013; Borowski, 2014; Powell, 2014)

What makes someone a good communicator? There's no mystery here, not since Aristotle identified the three critical elements - ethos, pathos, and logos. - thousands of years ago. Ethos is an appeal to the authority or credibility of the presenter. It is how well the presenter convinces the audience that he or she is qualified to present (speak) on the particular subject (Aristotle, 1909). Pathos is an appeal to the audience's emotions, and the terms pathetic and empathy are derived from it. It can be in the form of metaphor, comparing, a passionate delivery, or even a simple claim that a matter is unjust. Pathos can be particularly powerful if used well, but most speeches do not solely rely on pathos. Pathos is most effective when the author or speaker demonstrates agreement with an underlying value of the reader or listener. Logos is logical appeal or the simulation of it, and the term logic is derived from it. It is normally used to describe facts and figures that support the speaker's claims or thesis. Having a logos appeal also enhances ethos because information makes the speaker look knowledgeable and prepared to his or her audience (Aristotle, 1909).

By its aspects of trust, responsibility, revalidation, conviction conditions the efficiency of communication, even its existence. "To be able to convince - J. B. Grize affirms - it is not sufficient to enumerate phrases - (...) they must be articulated, meaning that we should reason by them" (Grize, 1990, p. 9). From the assumption created, the following question arises: is there communication also without installation of convictions? There is. When communication is not modulated by conviction, it shall be governed by manipulation, falsehoods (sophisms and absurd questions), the argument of force, in one word by "persuasion" (Siminică \& Traistaru, 2013; Traistaru \& Avram, 2014). On this idea, communication is divided into: convictive communication and persuasive communication. "Persuasion and diplomatic ability - according to A. Berger (Berger, 1976) - to a large extent consist in choosing the words, formulas and images showing the facts under a pleasant, favorable light, without necessarily being misleading". By various manoeuvers (seduction, intimidation, persuasive argumentation that is rather related to the rhetoric of subtle violence...), somebody succeeds to divert for their own benefit (and eventually for the represented group) the techniques and normal strategies of dialogue thusly counterfeited or obliterated (Vlăduţescu, 2014). To persuade $=$ to convince someone to believe, to think or to (want to) do a certain thing (leaves 
the truth aside). To convince $=$ to make someone adopt an opinion based on evidence and arguments, to make someone admit something as being true (DEX, 1996, 154, p. 681 and p. 194)

The studies on information theory by Claude Elwood Shannon, Warren Weaver and others, prompted research on new models of communication from other scientific perspectives like psychology and sociology. In science, a model is a structure that represents a theory (Frigg \& Hartmann, 2009). D. Chandler asserts regarding models developed by Shannon and Weaver that "They developed a model of communication which was intended to assist in developing a mathematical theory of communication. Shannon and Weaver's work proved valuable for communication engineers in dealing with such issues as the capacity of various communication channels in 'bits per second'. It contributed to computer science. It led to very useful work on redundancy in language. And in making 'information' 'measurable' it gave birth to the mathematical study of 'information theory' (Chandler, 1994).

Harold Lasswell (1902-1978), a political scientist and communication theorist, was a member of the Chicago school of sociology. In his work 'The Structure and Function of Communication in Society' (1948), he defined the communication process as Who (says) What (to) Whom (in) What Channel (with) What Effect. The distinct model he propounded was known as Dance Model (Lasswell, 1948).

Basic elements of communication made the object of study of the communication theory (Craig, 2001) of XXth century:

- Source: Shannon calls it information source, which "produces a message or sequence of messages to be communicated to the receiving terminal" (Shannon, 1948).

- Sender: Shannon calls it transmitter, which "operates on the message in some way to produce a signal suitable for transmission over the channel (Shannon, 1948). In Aristotle it is the speaker (Whately, Ehninger, Potter, 1963).

- Channel: For Shannon it is "merely the medium used to transmit the signal from transmitter to receiver(Shannon,1948)

- Receiver: For Shannon the receiver "performs the inverse operation of that done by the transmitter, reconstructing the message from the signal" (Shannon,1948)

- Destination: For Shannon destination is "the person (or thing) for whom the message is intended"(Shannon, 1948).

- Message: from Latin mittere, "to send". A concept, information, communication or statement that is sent in a verbal, written, recorded or visual form to the recipient.

- Feedback

- Entropic elements, positive and negative.

According to communication theorist Robert T. Craig in his essay 'Communication Theory as a Field' (1999), "despite the ancient roots and growing profusion of theories about communication," there is not a field of study that can be identified as 'communication $t$ In 1999 In this article Craig "proposes a vision for communication theory that takes a huge step toward unifying this rather disparate field and addressing its complexities"( Littlejohn, Foss, 2008). To move toward this unifying vision Craig focused on communication theory as a practical discipline and shows how "various traditions of communication theory can be engaged in dialogue on the practice of communication" (Craig, 1999).

In this deliberative process theorists would engage in dialog about the "practical implications of communication theories" (Craig, 2001). In the end Craig proposes seven different traditions of Communication Theory and outlines how each one of them would 
engage the others in dialogue (Craig, 1999). The standard traditions induces a rigid perspective that, although concerns, still does not allow long-term unification of the space communication theory. Although at the time of accreditation, the standard Craig-traditions was salutary, today it proves relatively inflexible: do not allow the development, growth, renewal, because it brings everything from the past (Vlăduţescu, 2013; Vlăduţescu, 2014; Vlăduțescu \& Ciupercă, 2013). In the field of communication, in addition to traditions are recorded spontaneous phenomena and theories, unconventional, non-traditional, and emerging phenomena and theories, relatively unexpected and unexplained.

Vladutescu's view is 'that a flexible standard of radiography and catagraphy of axiological is the standard of communication field. In communication we record 15 axes: communication ontology, communication epistemology, communication methodology, communication axiology, communication history, communication psychology, communication sociology, communication anthropology, communication hermeneutics, communication praxeology, communication ethics, communication logics, communication ecology, communication philosophy, communication law" (Vlăduţescu, 2014).

Communication, the transmission of information from a point called origin or source to another called destination or receiver (or audience), is the blood stream of every community. A community may be explained as a group of people who have lived together long enough to evolve common culture, norms and values. Culture distinguishes one society from another. Culture gives form and meaning to a people's existence. Culture is defined by Onigu and Ogionwo (Onigu, Ogionwo, 2006; Ceban, 2008) as "the complex whole of man's acquisitions of knowledge, morals, beliefs, arts, custom, technology, etc, which are shared and transmitted from generation to generation".

Culture includes those things which man has invented and produced and which we can see, feel, or hear, as well as those aspects of man's behaviour which we cannot see, namely, knowledge, beliefs or morals, language, philosophy, attitudes, etc. Communication which is an act, a process of interaction, is carried out primarily through the use of signs (or symbols). Such signs or symbols must arouse the same meaning in the other person (individual or group or people) as it does in one's self. Communication is an aspect of culture, the non-material culture. Indigenous and traditional communication modes and channels, therefore, have a sort of cultural relativity.

Such modes and channels are identified, assessed and understood in the context of the particular culture and its value system. Cultures are complex and multifaceted. As is apparent from the above discussions, cultures are complex "structures" that consist of a wide array of characteristics. The cultures of relationships or groups are relatively simple compared to those of organizations and, especially, societies. Edward Hall $(1959,1979)$ is one of the most significant contributors to the general understanding of the complexity of culture and the importance of communication to understanding and dealing with cultural differences at the societal level (Rogers, Hart \& Yoshitaka, 2002; Colhon, 2013).

\section{NEUTROSOPHIC COMMUNICATION}

Neutrosophy is a new branch of philosophy that studies the origin, nature, and scope of neutralities, as well as their interactions with different ideational spectra. This theory considers every notion or idea $\langle\mathrm{A}\rangle$ together with its opposite or negation $<$ antiA $>$ and with their spectrum of neutralities <neutA> in between them (i.e. notions or ideas supporting neither $\langle\mathrm{A}\rangle$ nor $\langle$ antiA $\rangle$ ). The $\langle$ neutA $>$ and $\langle$ antiA $>$ ideas together are referred to as 
$<$ nonA $>$. Neutrosophy is a generalization of Hegel's dialectics (the last one is based on $<\mathrm{A}\rangle$ and $\langle$ antiA $>$ only) (Smarandache 1999, 2002). According to this theory every idea $\langle A\rangle$ tends to be neutralized and balanced by $\langle$ antiA $>$ and $\langle$ nonA $>$ ideas - as a state of equilibrium. In a classical way $\langle\mathrm{A}\rangle$, $\langle$ neutA $\rangle$, $\langle$ antiA $\rangle$ are disjoint two by two. But, since in many cases the borders between notions are vague, imprecise, Sorites, it is possible that $\langle A\rangle$, $\langle$ neutA $\rangle$, $<$ antiA > (and <nonA> of course) have common parts two by two, or even all three of them as well (Smarandache, 1999, 2002). Neutrosophy is the base of neutrosophic logic, neutrosophic set, neutrosophic probability, and neutrosophic statistics that are used in engineering applications (especially for software and information fusion), medicine, military, airspace, cybernetics, physics (Smarandache, 1999).

The neutrosophics was introduced by professor Florentin Smarandache in 1995. Together with professor Stefan Vladutescu, they enlarged the neutrosophic theory to social sciences, a clinching example is the recently book, "Communication Neutrosophic Routes", 2014, Columbus, OH: Educational Publishing. Neutrosophy handles all neutralities. In the neutrosophic taxonometry, a class of neutralities is represented by the neutralities that without turning into contradictions, generate qualitative leaps. The emergence is the cognitive phenomenon in which, from two or more connected neutralities, without contradiction, a change of quality or a qualitative leap result. Thinking in Hegelian terms has an axiom the idea that the qualitative change, the qualitative leap take place only in contradiction. Neutrosophy claims that qualitative emergences may arise from related neutral items (Smarandache, Vladutescu, 2014).

Neutrosophic emergences are the unexpected occurrences of some major effects from the interaction of some minor qualitative elements. Emergences would be seen as a major phenomenon occurrence, important and significant from the reaction of two or more minor unimportant, insignificant elements. On the other hand netrosophic incidence can be applied as applications of a law, an axiom, an idea, a conceptual accredited construction on an unclear, indeterminate phenomenon, contradictory to the purpose of making it intelligible. The incidence is intelligibilization procedure using the concept: basically apply a previous theoretically validated concept is practically applied. If the emergence is a variant of the cognitive bottom-up processing, the incidence is a variant of the top-down cognitive processing (Hintea, 2013; Smarandache \& Vladutescu, 2014; Vladutescu, 2014).

Communicational relations always comprise a set of neutral, neutrosophic meanings. Communication in general is a human manifestation of life with recognizable profile. Particularly, we talk about scientific communication, literary communication, pictorialcommunication, sculptural communication, esthetic communication and so on, as specific manifestations of life.

All of these include coherent, cohesive and structurable series of existential meanings which are contradictory and/or neutral, neutrosophic. It can be asserted that in any communication there are routes of access and neutrosophic routes. Any communication is traversed by neutrosophic routes of communication. Any communication is accompanied by interpretation; sharply, aesthetic communication, by its strong ambiguous character, forces the interpretation.

Since, due to comprehension, description and explanation, the interpretation manages contradictions, understanding conflicts and roughness of reading, aesthetic interpretation is revealed as a deeply neutrosophicinterpretation. Communication and aesthetic interpretation prevalently manage neutralities but contradictions (Smarandache, Vladutescu, 2014). 


\section{VIRAL COMMUNICATION}

"Viral marketing" may sound strange to those who have never encountered the term. It may strike you as to how a term like viral could be incorporated into the marketing industry terminology? Well, your doubts may hold the reigns of validity. It certainly delivers a deceitful connotation to those who don't gather the slightest idea of the concept. Ironically, this is one concept that also grabs eyeballs in creating self-awareness (Schroeder, 2010). Viral marketing matches up to define itself as a thoughtful marketing strategy that concentrates on spreading awareness about a particular product; thereby, also maintains the word-of-mouth ideology. It is the marketing industry that systematically uses the terminology to elicit interest in the masses through the Internet (Arsith \& Draganescu, 2011; Burman, 2012). The communication process is such that the most important information which may attract the attention and interest of the consumer is put forth, or is circulated through the word-of-mouth technique (Pariñas, 2011).

The communication process may be termed as 'viral fire'. I say this, as I believe that to a certain extent, viral marketing works on the principle of how a virus is communicable in nature. It is through the virus spreading that many people may endure common colds, or fevers; in the same manner, it is only through viral marketing that there are people who pass on a good word about the product, or service they have availed of, and found it beneficial, or satisfying. It serves to be a virtual propagator that spreads the news, through its marketing strategies. There are essentially two ways in which the communication takes place: spontaneous and planned (Burman, 2012).

The spontaneous viral communication is a strategy that focuses on the provision of a product or service by the company. When the customers or consumers are satisfied, they would provide their feedback in the form of availing the service or the product all over again and continuing to use their offered methods. Through this method, those who have used this product will pass on their positive impression to friends or potential buyers who may be interested in the services and the product. In turn they may do the same for the ones they know. In a short period, you would have a number of people using the product or the service (Rayport, 1996; Burman, 2012).

A method to accomplish a success viral communication campaigne is Planned Communication. A research conducted by Phelps et al. (2004), produced a forensic report publishing the efficacy and frequency of forwarding emails, with regards to classifying the email mode of communication into four sections. They also found that emails eliciting specific human emotions highlighting its minutiae, have a greater probability of being passed on. Emails that function as virtual bulletin boards are likely to garner attention by the receiver. Thus, while indulging in viral marketing, emails proves to be a strategic instrument for effective and agile communication pathway (Rayport, 1996; Burman, 2012). The email is, therefore, a model of planned communication. Planned communication is a program set up by the company or the organization to let the masses know about the products or services they have on offer. The communication process has a planned strategy that functions on the principle of the following elements:"Take Away Products", "Easily Communicable Messages", "Preparation for Varied Response", "Concentrate on the Typical Human Mentality", "Human Communication Networks" (Rayport, 1996; Schroeder, 2010 ).

The existing human communication networks are the most successful and effective, as they have close contacts and relations through networks on the Internet and social networking sites (Cojocaru, 20110; Cojocaru \& Cojocaru, 2011; Dima \& Vlăduţescu, 2012). This is the strongest way through which messages can be sent and passed on. They are instant, and don't 
require the individual to invest more time, the easiest procedure of using persuasion methods as myth, seduction, fiction, lie. This is how the communication process of viral marketing materializes.

\section{CONCLUSIONS}

The world is evolving in all areas, both areas of logistics, software and hardware. Technology is advancing too fast, communication, relationships have to keep up with it. Information is transmitted at high speed, the case of viral communication, the world does not have time to check everything forward, some information is poisoned, part of the negative communication. Conviction and persuasion intend to be at least programmable and externally convictive and convincing. The difference between them is that the conviction decisively rely on convincing, on transferring an internal conviction, on inducing a conviction. In return, the persuasion decisively relies on persuading, on inducing an external conviction, which is known to be illegitimate and one interestedly promotes it.

\section{ACKNOWLEDGMENT}

This work was partially supported by the grant number 33C/2014, awarded in the internal grant competition of the University of Craiova.

\section{References}

[1] Robert T. Craig (1999). Communication Theory as a Field. International Communication Association. Retrieved 06.06.2014.

[2] Andrzej Borowski, International Letters of Social and Humanistic Sciences 14 (2014) 7-17.

[3] Jason L. Powell, International Letters of Social and Humanistic Sciences 16(2) (2014) 177-183.

[4] Ştefan Vlăduţescu, European Scientific Journal 9(32) (2013).

[5] Roman Frigg, Stephan Hartmann (2009). Models in Science. The Stanford Encyclopedia of Philosophy. Retrieved 06.06.2014.

[6] Daniel Chandler, (1994). The Transmission Model of Communication. University of Western Australia. Retrieved 06.06.2014.

[7] Harold Dwight Lasswell (1948). The Structure and Function of Communication in Society. New York: Lyman Bryson.

[8] Ioan Constantin Dima, Ştefan Vlăduţescu (2012). Persuasion elements used in logistical negotiation: Persuasive logistical negotiation. Saarbrucken: LAP Lambert Academic Publishing.

[9] Andrzej Borowski, International Letters of Social and Humanistic Sciences 14 (2014) 33-41. 
[10] Claude Elwood Shannon (1948). A Mathematical Theory of Communication. The Bell System Technical.

[11] Marian Siminică, Aurelia Traistaru, International Journal of Education and Research 1(12) 2013.

[12] A. Traistaru, M. Avram, International Letters of Social and Humanistic Sciences 13 (2014) 79-88.

[13] Alina Tenescu, Mirela Teodorescu, Communications in Applied Sciences 2(1) (2014).

[14] Ştefan Vlăduţescu (2013). What Kind of Communication Is Philosophy. Jokull.

[15] Alexandra Iorgulescu (2014). Neutrosophic Inflexions in Seneca's Tragedy. Communication Neutrosophic Routes.

[16] Andrzej Borowski, International Letters of Social and Humanistic Sciences 4 (2013) 70-74.

[17] M. Nowicka-Skowron, S. M. Radu (2014). The information and company's innovativecreative activity under the current conditions of the market economy. Communication Neutrosophic Routes.

[18] D. Cojocaru, S. Cojocaru, Revista de Cercetare şi Intervenţie Socială 33 (2011) 209-222.

[19] A. I. Motei, Studia Universitatis Babes-Bolyai-Ephemerides 2 (2008) 41-52.

[20] Ş. Vlăduţescu, E. M. Ciupercă (2013). Next Flood Level of Communication: Social Networks. Aachen: Shaker Verlag.

[21] D. M. Popa, Anuarul Universităţii" Petre Andrei” Iaşi-Fascicula Drept, Ştiinţe Economice, SStiinţe Politice 08 (2011) 395-402.

[22] A. Borowski, International Letters of Social and Humanistic Sciences 11 (2014) 1-168

[23] Mădălina Cerban, Annales Universitatis Apulensis. Series Philologica I(2) (2008) 173-178.

[24] M. Arsith, O. Draganescu (2011). Communication and Organizational Culture. EIRP Proceedings.

[25] L. Roşca, Revista Română de Comunicare şi Relaţii Publice (4) (2011) 101-103.

[26] Ștefan Vlăduțescu (2013). Principle of the Irrepressible Emergence of the Message. Jokull.

[27] Colhon M. (2013). Automatic Lexical Alignment between Syntactically Weak Related Languages. Application for English and Romanian. In Computational Collective Intelligence. Technologies and Applications (pp. 266-275). Springer Berlin Heidelberg.

[28] Daniela Gîfu, Mirela Teodorescu, International Letters of Social and Humanistic Sciences 18 (2014) 34-38.

[29] Richard Whately, Douglas Ehninger, David Potter (1963). Elements of Rhetoric: Comprising an Analysis of the Laws of Moral Evidence. Southern Illinois University Press.

[30] Otite Onigu, William Ogionwo (2006). Introduction to Sociological Studies. Heinemann Educational Books PLC. Ibadan. 
[31] Douglas Harper, Communication. Online Etymology Dictionary. Retrieved 2014-06-06.

[32] Julia Scherba de Valenzuela (1992). American Speech-Language-Hearing Association (ASHA): Guidelines for Meeting the Communication Needs of Persons With Severe Disabilities.

[33] Florentin Smarandache, Ştefan Vlăduţescu (2014). Communication Neutrosophic Routes. Columbus, $\mathrm{OH}$ : Educational Publishing.

[34] H. A. Innis (1951). The bias of communication. Toronto: University of Toronto Press.

[35] David Diringer (1982). The Book Before Printing: Ancient, Medieval and Oriental. Courier Dover Publications.

[36] Daniela Gîfu, Mirela Teodorescu, International Letters of Social and Humanistic Sciences 17 (2014) 119-127.

[37] Andrezj Borowski, International Letters of Social and Humanistic Sciences 2 (2014) 110-121.

[38] Ştefan Vlăduţescu, International Letters of Social and Humanistic Sciences 10(2) (2014) 100-106.

[39] Aristotle (1909). The Rhetoric of Aristotle (trans. - Richard C. Jebb). Cambridge: University Press.

[40] Stephen Littlejohn, Karen Foss (2008). Theories of Human Communication (9 ed.). Thomson and Wadsworth.

[41] F. Smarandache (1999). A Unifying Field in Logics: Neutrosophic Logic. Philosophy.

[42] F. Smarandache (2002). Neutrosophy, a new Branch of Philosophy. Multiple Valued Logic.

[43] Florentin Smarandache, Ştefan Vlăduţescu (2014). Neutrosophic Emergences and Incidences. Saarbrucken: LAP Lambert Academic Publishing.

[44] H.-G. Gadamer (2001). Adevăr şi metodă. Bucureşti: Editura Teora.

[45] Everett M. Rogers, William B. Hart, Miike Yoshitaka (2002). Edward T. Hall and the History of Intercultural Communication: The United States and Japan. Keio Communication.

[46] Andrezj Borowski, International Letters of Social and Humanistic Sciences 3 (2013) 69-74.

[47] Ştefan Vlăduţescu, Communications in Applied Sciences 2(1) (2014).

[48] DEX (1996). Bucureşti: Editura Univers Enciclopedic

[49] J. B. Grize (1990). Logique et langage. Paris: Ophrys.

[50] J. T. Burman, Perspectives on Science 20(1) (2012) 75-104.

[51] Jeffrey Rayport (1996). The Virus of Marketing. Fast Company. Retrieved 6 june 2014.

[52] Ştefan Vlăduţescu (2014). Accenting of the negative journalism in economic crisis periods. International.

[53] Jerico Pariñas (2011). Spread the Words through Viral Marketing. XING. Retrieved 19 January 2014. Books. 
[54] Stan Schroeder (2010). Social Networks Play a Major Part in How We Get News. Columbus.

[55] A. Traistaru (2013). Consolidation of the green marketing profile in current austerity period. Jokull.

[56] Janusz Grabara, Vladimir Modrak, Ioan Constantin Dima, International Letters of Social and Humanistic Sciences 15 (2014) 148-156.

[57] Ştefan Vlăduțescu, Journal of Sustainable Development Studies 6(1) (2014).

[58] C. E. Hintea, Revista de Cercetare şi Intervenţie Socială 42 (2013) 294-309.

[59] F. C. Macarie, C. Hinţea, Cristina Mora, Transylvanian Review of Administrative Sciences 32(E) (2011) 146-156.

[60] Jason L. Powell, International Letters of Social and Humanistic Sciences 16(2) (2014) 108-121.

[61] Stefan Vladutescu, Analele Universităţii din Craiova. Seria Ştiinţe Filologice. Lingvistică (1-2) (2013) 355-363.

[62] C. Gavrilovici, L. Oprea, Revista Romana De Bioetica 11(3) (2013).

[63] S. Cojocaru, Journal for the Study of Religions and Ideologies 4(10) (2010) 36-48.

[64] Janusz Grabara, Ion Cosmescu (2014). Use of computer engineering in company's commercial and transport logistics. Communication Neutrosophic Routes.

[65] Jason L. Powell, International Letters of Social and Humanistic Sciences 7 (2014) 22-30.

[66] Jason L. Powell, International Letters of Social and Humanistic Sciences 16(2) (2014) 132-143.

[67] Goran Rajović, Jelisavka Bulatović, International Letters of Social and Humanistic Sciences 15(2) (2014) 125-137.

[68] Nirmal Kumar Betchoo, International Letters of Social and Humanistic Sciences 16(1) (2014) 39-48.

[69] Jason L. Powell, International Letters of Social and Humanistic Sciences 16(2) (2014) 177-183.

[70] Jacek Tittenbrun, International Letters of Social and Humanistic Sciences 9 (2014) 26-48.

[71] Jason L. Powell, International Letters of Social and Humanistic Sciences 17(1) (2014) 1-60. 